Article

\title{
Evaluation of the Physical, Chemical and Thermal Properties of Portuguese Maritime Pine Biomass
}

\author{
Helder Filipe dos Santos Viana ${ }^{1,2, *(1)}$, Abel Martins Rodrigues ${ }^{3,4}$, Radu Godina ${ }^{5}$ (i), \\ João Carlos de Oliveira Matias 6,7 (i) and Leonel Jorge Ribeiro Nunes ${ }^{6,7}$ \\ 1 Centre for the Research and Technology of Agro-Environmental and Biological Sciences, CITAB, \\ University of Trás-os-Montes and Alto Douro, UTAD, 5001-801 Vila Real, Portugaly \\ 2 Agrarian Superior School, Polytechnic Institute of Viseu, 3504-510 Viseu, Portugal \\ 3 Departamento de Tecnologia e Inovação, INIAV-Instituto Nacional de Investigação Agrícola e Veterinária, \\ 2780-157 Oeiras, Portugal; abel.rodrigues@iniav.pt \\ 4 Maretec Research Centre, Instituto Superior Técnico, Av. Rovisco Pais, 1049-001 Lisboa, Portugal \\ 5 C-MAST-Centre for Aerospace Science and Technologies-Department of Electromechanical Engineering, \\ University of Beira Interior, 6201-001 Covilhã, Portugal; rd@ubi.pt \\ 6 DEGEIT_Department of Economics, Management, Industrial Engineering and Tourism, \\ University of Aveiro, 3810-193 Aveiro, Portugal; jmatias@ua.pt (J.C.d.O.M.); leonelnunes@ua.pt (L.J.R.N.) \\ 7 GOVCOPP - Research Unit on Governance, Competitiveness and Public Policies, University of Aveiro, \\ 3810-193 Aveiro, Portugal \\ * Correspondence: hviana@esav.ipv.pt; Tel.: +351-232-446-600
}

Received: 30 July 2018; Accepted: 9 August 2018; Published: 13 August 2018

check for updates

\begin{abstract}
A characterisation of Pinus pinaster Aiton. (Maritime Pine) woody biomass and ashes is presented in this study. Physical, thermal and chemical analysis, including density, moisture content, calorific value, proximate and ultimate analysis, were carried out. The fuel Energy Density $\left(E_{d}\right)$ and the Fuelwood Value Index (FVI) were assessed by ranking the fuelwood quality. Furthermore, the determination of the ash metal elementals was performed. The results from this study indicated, for Pinus pinaster biomass tree components, carbon content ranging from 46.5 to $49.3 \%$, nitrogen content from 0.13 to $1.18 \%$, sulphur content from 0.056 to $0.148 \%$ and hydrogen content around $6-7 \%$. The ash content in the tree components ranged from 0.22 to $1.92 \%$. The average higher heating value (HHV) was higher for pine needles $\left(21.61 \mathrm{MJ} \cdot \mathrm{kg}^{-1}\right)$. The $E_{d}$ of $8.9 \mathrm{GJ} \cdot \mathrm{m}^{-3}$ confirm the good potential of Pinus pinaster biomass tree components as fuel. The FVI ranked the wood stem (4658) and top (2861.8) as a better fuelwood and pine needles (394.2) as inferior quality. The chemical composition of the ashes revealed that the elemental contents are below the national and most European countries legislation guidelines for the employment of ash as a fertiliser.
\end{abstract}

Keywords: biomass; Pinus pinaster; fuel; heating value; fuelwood value index; energy density; ash recovery

\section{Introduction}

Maritime pine (Pinus pinaster Aiton.) is the second species in terms of occupied area in Portugal, accounting for around $23 \%$ of forest area, occurring mostly in the north and central regions of Portugal [1]. An estimation made in 2010 for NUTS II (Nomenclature of Territorial Units for Statistics) reported a yearly average of 579.9 thousand dry tons, ranging between 400.96 thousand dry tons per year and 673.54 thousand dry tons per year [2].

In 2017, forest fires were particularly severe, with a forest area of about 500,000 ha burned in the country and, presently, a large amount of biomass supply is available for conversion [3-5].

The energy acquired from biomass is distinguished and remarkable in that it can be obtained without difficulty and is also renewable [6]. It promotes the protection of the environment, since biomass is abundant, 
natural, and reusable [7]. The chemical composition and physical properties of biomass ashes and biomass components, wherein the latter is strictly linked to its anatomic polymeric structure, are determinant for the performance of thermochemical conversion of the feedstocks [8-12]. Biomass shows highly variable chemical composition and properties regarding moisture, structural and inorganic components, which is related to the myriad plant growth processes and growing conditions [13]. The main and less important elements of biomass, in diminishing order of quantity, are normally the following: $\mathrm{C}, \mathrm{O}, \mathrm{H}, \mathrm{N}, \mathrm{Ca}, \mathrm{K}, \mathrm{Si}, \mathrm{Mg}$, $\mathrm{Al}, \mathrm{S}, \mathrm{Fe}, \mathrm{P}, \mathrm{Cl}$ and $\mathrm{Na}$, in addition to $\mathrm{Mn}$, Ti and other trace elements. Typical proximate analysis of maritime pine components shows values ranging between $65 \%$ to $72 \%$ for volatiles, $12.5 \%$ to $21 \%$ for fixed carbon, and $0.2 \%$ to $2.6 \%$ for ash content. Typical values for ultimate analysis of $C, H, N$, and $O$ range between $46 \%$ and $56 \%, 5 \%$ and $6 \%, 0.1 \%$ and $0.9 \%$, and $31 \%$ and $37 \%$, respectively. Sulphur amounts are negligible. Finally, the High Heating Value (HHV) ranges from $18 \mathrm{MJ} \cdot \mathrm{kg}^{-1}$ to $17 \mathrm{MJ} \cdot \mathrm{kg}^{-1}$ [14].

As a comparison, for coal, the carbon content is, on average, about $80 \%$ or higher, the oxygen about $8 \%$ or lower, and the $N$ and $S$ are about $1.8 \%$ and $0.8 \%$ or higher, respectively. Fixed carbon and volatile amounts for coal are of the order of $50 \%$ and $44 \%$, respectively. HHV and LHV for coal are of $35 \mathrm{MJ} \cdot \mathrm{kg}^{-1}$ and $33 \mathrm{MJ} \cdot \mathrm{kg}^{-1}$, respectively. This chemical profile fits the overall picture that woody biomasses posit advantages over fossil fuels such as coal related to carbon neutrality and reduced emissions of $\mathrm{SO}_{2}$ and $\mathrm{NO}_{x}$ [13]. However, handicaps of woody biomass, such as lower energy density and calorific values, hygroscopic properties, and high moisture content leading to degradation and self-heating, make the handling and transportation costlier and more complex.

Torrefaction of the feedstock is an option for minimising these drawbacks and making the chemical profile of torrefied biomass closer to that of coal. Biomass torrefaction is a thermochemical pre-treatment, carried out in the absence of oxygen at temperature ranges of about $220^{\circ} \mathrm{C}$ to $320^{\circ} \mathrm{C}$, delivering a product with lower $\mathrm{O} / \mathrm{C}$ and $\mathrm{H} / \mathrm{C}$ ratios, closer to typical coal ratios [15]. The torrefied products are more homogeneous and show higher energy density and grindability [16]. Also, the similarity of the torrefied pulverised product to coal powder makes possible its co-firing, at amounts as high as $40 \%$, with coal in power plants [17]. Experimental evidence with torrefaction of maritime pine carried out at a lab scale made it possible to obtain a torrefied product with a LHV of $22.6 \mathrm{MJ} \cdot \mathrm{kg}^{-1}$, corresponding to a gain of about $20 \%$, a C amount of $65 \%$ (15\% gain), a fixed carbon amount of 30\% (35\% gain) and $29 \%$ for oxygen amount, corresponding to a decrease of $21 \%$ from raw biomass [18]. Thereby, the ratio of $\mathrm{O} / \mathrm{C}$ decreased by $32 \%$ for torrefied maritime pine biomass. The ratio of torrefied pine biomass also decreased by $18 \%$. The LHV in conifers is on average $2 \%$ higher than in hardwoods. This difference occurs due to a higher lignin content, and sometimes due to the higher resin, oil and wax content present in conifers [18]. Indeed, while LHV for cellulose ranges between $17.2 \mathrm{MJ} \cdot \mathrm{kg}^{-1}$ and $17.5 \mathrm{MJ} \cdot \mathrm{kg}^{-1}$ and is about $16 \mathrm{MJ} \cdot \mathrm{kg}^{-1}$ for hemicelluloses, in lignin, LHV is higher, ranging between $26 \mathrm{MJ} \cdot \mathrm{kg}^{-1}$ and $27 \mathrm{MJ} \cdot \mathrm{kg}^{-1}$. A slight variability in the calorific value can be witnessed and occurs due to certain variability in the elementary $H$ content. It also occurs as a result of a much larger variability in ash contents [19].

Low heating value is a variable which allows evaluating the enthalpy released in forest fires through the combustion of fuels available in the field surface, thereby providing additional information about the easiness of fire propagation. The LHV of the different forest canopy components is thereby one valuable indicator of the energetic status of forest biomass which helps to optimise the management of the energetic forest resources in the field. In [20], data is presented for the seasonal variability of biomass flammability and the heating value of maritime pine woody biomass components in NW Spain.

The Fuelwood Value Index (FVI), expressed in MJ.m $\mathrm{m}^{-3}$ and defined as the ratio between the products between the calorific power and density and between the ash and moisture contents, is another relevant variable for ranking the fuel aptitude of woody biomasses for different species [21].

Energy density $\left(E_{a}\right)$, expressed in $G J \cdot m^{-3}$, defined as the product between LHV and bulk density, is another variable that can be assessed in order to identify the potential and to choose a fuel for use in small-scale heating plants and households. The energy density is relevant for woody fuels, because its storage and transport could be cheaper and more efficient at a higher energy density. 
Another factor that could be taken into consideration is the evaluation of biomass ashes, concerning either its chemical composition as the mechanisms and quantities produced in the thermo-chemical conversions. Biomass ashes are made up of $\mathrm{Cl}$ and $S$, with major elements $(A l$, $\mathrm{Ca}, \mathrm{Fe}, \mathrm{K}, \mathrm{Mg}, \mathrm{Na}, \mathrm{P}, \mathrm{Ti}, \mathrm{Si}$ ) and minor or trace elements (As, $\mathrm{Ba}, \mathrm{Cd}, \mathrm{Co}, \mathrm{Cr}, \mathrm{Cu}, \mathrm{Hg}, \mathrm{Mn}, \mathrm{Mo}, \mathrm{Ni}, \mathrm{Sb}, \mathrm{Pb}$, $\mathrm{Tl}, V, \mathrm{Zn})$. In comparison with coal, biomass usually shows higher amounts, in decreasing order, of $\mathrm{Mn}, \mathrm{K}, \mathrm{P}, \mathrm{Cl}, \mathrm{Ca}, \mathrm{Mg}, \mathrm{Na}, \mathrm{O}$ and $\mathrm{H}$, and lower amounts of ash, $\mathrm{Al}, \mathrm{C}, \mathrm{Fe}, \mathrm{N}, \mathrm{S}, \mathrm{Si}$, and Ti.

Elements included in biomass ashes can be divided in two classes: intrinsic or inherent chemicals bonded to a carbon structure, and entrained elements that can come with biomass as mineral soil particles that have been incorporated into biomass during plant growth, or taken away during harvesting and transport [22]. These elements are relevant for aerosol emissions, ash melting, deposit formation, fly ash and corrosion, and also for the utilisation/disposal of the ashes.

During combustion, some volatilisation of ash-forming compounds occurs, with the volatised fraction depending on factors such as the technology employed, chemical composition of the fuel, operative temperature, and surrounding gas atmosphere. Indeed, volatilisation of heavy metals such as $\mathrm{Pb}, \mathrm{Cd}$ and $\mathrm{Zn}$ can happen under high operative temperatures and low oxidising atmospheres. Toxicity due to heavy metals $(\mathrm{Cu}, \mathrm{Zn}, \mathrm{Cr}, \mathrm{Cd}, \mathrm{Mn}, \mathrm{Ni}$ or $\mathrm{Pb})$ can cause serious consequences in soils located in sites corresponding to former agricultural areas with excessive use of fertilisers, fungicides and insecticides. Dangerous trace elements in the form of salts are highly mobile on the ashes, but issues related to their accessibility and availability still lack some fundamental knowledge. For example, these trace elements may be water soluble or bound into glass, which is formed from the fusion of inorganic material in biomass [14].

Some toxic elements such as $\mathrm{As}, \mathrm{Cd}, \mathrm{Cr}, \mathrm{Pb}, \mathrm{Cu}, \mathrm{Mn}, \mathrm{Fe}, \mathrm{Ni}$, and $\mathrm{Zn}$ are described in the literature with concentrations as high as $243 \mathrm{ppm}, 657 \mathrm{ppm}, 0.17 \%, 5 \%, 0.24 \%, 4.7 \%, 25 \mathrm{ppm}, 0.5 \mathrm{ppm}$ and $16.4 \%$ in fly ashes, respectively (e.g., [23]). Plant growth and biomass can thereby be drastically affected by release of these elements.

Typical ranges in ash element composition of biomass tree components (wood, bark, leaves, tops or branches) for $\mathrm{Fe}, A l, A s, \mathrm{Cd}, \mathrm{Pb}, \mathrm{Co}, \mathrm{Cu}, \mathrm{Cr}, \mathrm{Mn}, \mathrm{Zn}$, and $\mathrm{Ni}$ are 3000-40,000, 4700-74,000, 3-60, 0-25, $15-650,<1-20,15-400,10-250,1000-30,000,15-4400$ and 6-200 $\mathrm{mg} \cdot \mathrm{kg}^{-1}$, respectively [14]. In industrial areas, nickel toxicity is particularly acute, at high soil concentrations above a threshold of $200 \mathrm{ppm}$ with drastic physiological consequences. Excess $C d$ exerts similar effects in plants, and damage to root cells has been reported on grey poplar. Plant growth, biomass production, shoots and root lengths has been ascribed to arsenic contamination in soils as a result of the widespread use of arsenical pesticides. Thereby, heavy metals in biomass ash, e.g., $\mathrm{Zn}, \mathrm{Cu}, \mathrm{Cd}, \mathrm{Cr}$ and $\mathrm{Pb}$ above certain limits, are surely toxic to plants, precluding their use as fertiliser, insofar as its application to soil can constitute a potential source of contamination for aquatic and terrestrial ecosystems [24,25].

Under this negative environmental context, there are strict regulations in some countries, e.g., in North and Central Europe, specifying thresholds on amounts of elements such as $\mathrm{Co}, \mathrm{Cr}, \mathrm{K}, \mathrm{N}, \mathrm{Cu}, \mathrm{V}, \mathrm{Zn}, \mathrm{Ca}, \mathrm{Cd}$, $\mathrm{Cl}, \mathrm{Ni}, \mathrm{S}$ or $\mathrm{Pb}$ in biomass fuels and ashes, considering all possible forms of conversion [26,27].

The assessment of ash use in forestry and agriculture differs between European states, to some extent due to different conditions [28]. While in some countries, mainly the Nordic countries of Europe, the use of ashes is a key factor for the replenishment of nutrients to acidic and poor soils; in other countries, such problems are not so deep and are therefore less worrisome. On the other hand, the logging of forest residues for energy production is made in a superior extent, extracting a large amount of nutrients in biomass. For instance, in Sweden, the recycling of ash is deemed to be a significant measure for forestry sustainability, while in Finland, the ash is considered to be a fertiliser and is used to increase the growth of forests growing on peatlands. As another example, in Denmark, ash recycling is deemed to be a method to make up for the loss of phosphorous and potassium [29]. As a consequence, several producers of wood in Northern America and Europe are beginning to recycle ash on an operational scale. For instance, in Finland, over $10 \%$ of wood and bark ash created 
by forest industry returns to the forest [30], as the wood ash is dispersed at high rates in many forests (in Finland 3-5 th ha ${ }^{-1}$ and in Sweden 1-3 thha ${ }^{-1}$ ).

The present work, under all of the above context, aims to evaluate the chemical composition and physical properties of the maritime pine biomass, considering proximate, ultimate and ash analysis in the tree components stem, tops, branches and needles, sampled from 16 plots in the Northern Portuguese county of Viseu.

\section{Materials and Methods}

\subsection{Stand Measurements and Biomass Samples for Fuel and Ash Analysis}

The biomass samples for fuel and ash analysis were collected from 16 maritime pine stands, located in the Viseu country in Northern-Central Portugal, where maritime pine mainly occurs.

The forest stands were measured and the structural stand variables such as number of trees per hectare $(N)$, dominant tree height class $\left(h_{\text {dom }}\right)$, basal area $(G)$, stand age $(t)$, crown closure class $(C c)$ and site index $(S I)$ were calculated, and the aboveground biomass quantified by destructive approach.

In each field plot, a biomass sample of each tree component (wood stem, top, branches and leaves) was collected and the sampled mixed biomass gave a typical tree sample per plot, totalling thereby sixteen typical trees, a concept useful for heat and mass balance evaluations in a burned forest area of maritime pine such as that. The collected samples were positioned inside hermetically closed containers with the intention of avoiding the loss of moisture, and were then sent to the laboratory.

The preparations and homogenisation of the samples, previous to the analytical measurements, were carried out by following the technical specifications of the CEN/TS 14780:2005 standard for sample preparations. The results on physical properties, proximate, and ultimate analysis were with respect to a typical tree per plot, according to the biomass sampling mentioned above.

\subsection{Analytical Measurements}

\subsubsection{Physical Properties}

The moisture content, as wet basis, was assessed according to the European Standard CEN EN 14774-1:2009, which consists of the drying of the sample in a drying oven at a temperature within the range of $105 \pm 2{ }^{\circ} \mathrm{C}$ in atmospheric air until a constant mass is reached. The percentage of moisture is assessed from the mass loss of the sample. Density $(D)$ and basic density on dry basis $\left(D_{b}\right)$ of tree components was assessed by using the technique of water displacement and is presented as the weight per unit volume [31].

\subsubsection{Proximate Analysis}

The assessment of the ash content (in the case of the dry basis) was performed according to CEN EN 14775:2009 standard. The ash content (\%) was calculated from the mass of the residue remaining after $1 \mathrm{~g}$ of oven-dried sample inside a platinum crucible was heated in a muffle furnace at $550{ }^{\circ} \mathrm{C} \pm 10^{\circ} \mathrm{C}$.

The volatile matter content (dry basis) was determined according to CEN EN 15148:2009, by burning $1 \mathrm{~g}$ of oven-dried sample in a fused silica crucible with lid on and heated in a muffle furnace at $900{ }^{\circ} \mathrm{C} \pm 10{ }^{\circ} \mathrm{C}$ for $7 \mathrm{~min}$. The overall percentage of the volatile matter was assessed from the mass loss of the test sample. The fixed carbon content (\%) was assessed as the difference between the totality of volatile matter and ash contents from $100 \%$. A minimum of 3 test runs were performed for every analysis, and the average of the two closest results (less than $5 \%$ variation) was taken as the measured value.

\subsubsection{Ultimate Analysis}

The elemental composition of the biomass with respect to carbon $(C)$, hydrogen $(H)$ and nitrogen $(N)$ and sulphur $(S)$ was measured by the standard methods of analysis. CEN/TS 15104:2005 and 
CEN/TS 15289:2006 describe the instrumental method for determining CHN and S, respectively, in solid biofuels. The concurrent assessment of the CHN was performed with the aid of Leco TruSpec ${ }^{\circledR}$ Elemental Determinator [32].

A sample of wood fuel powder, of circa $0.1 \mathrm{~g}$, is burned in an oxygen/carrier gas mixture by strictly following several conditions that guarantee a full combustion and that also guarantee the conversion of a few by-products to water vapour, carbon dioxide and nitrogen for gas analysis. The determination of sulphur was carried out in a Leco SC-144DR ${ }^{\circledR}$ machine by employing infrared detection and direct combustion. Duplicate calibration and determination techniques were made to guarantee a robust result consistency. The values of oxygen content were achieved by subtracting, as percentages, from $100 \%$ the total of $C, H, N, S$ and ash contents.

\subsubsection{Determination of the Low and High Heating Values}

High Heating Value (HHV) and Low Heating Value (LHV) were assessed by using a Parr $6400^{\circledR}$ calorimeter, and strictly following the EN 15296 [33] and EN 14918 [34] standards and also by following the standard operating and calculating instructions of the abovementioned equipment.

\subsubsection{Fuelwood Value Index (FVI) and Energy Density $\left(\mathrm{E}_{\mathrm{d}}\right)$}

The Fuel Value Index (FVI) is a parameter for ranking fuelwood species. FVI is calculated as the product of calorific value $\left(\mathrm{MJ} \cdot \mathrm{kg}^{-1}\right)$ and density $\left(\mathrm{g} \cdot \mathrm{cm}^{-3}\right)$ of the biomass by the product of ash content $\left(\mathrm{g} \cdot \mathrm{g}^{-1}\right)$ and water content $\left(\mathrm{g} \cdot \mathrm{g}^{-1}\right)$ as presented in Equation (1) [35,36]:

$$
\mathrm{FVI}=\frac{\text { Calorific Value }\left(\mathrm{MJ} \cdot \mathrm{Kg}^{-1}\right) \times \text { Density }\left(\mathrm{g} \cdot \mathrm{cm}^{-3}\right)}{\text { Ash Content }\left(\mathrm{g} \cdot \mathrm{g}^{-1}\right) \times \text { Moisture Content }\left(\mathrm{g} \cdot \mathrm{g}^{-1}\right)}
$$

Since the content of the moisture of the wood fluctuates with the proportions of the plant and also fluctuates with the season of the year and other variables, the water content is not treated as a factor of the intrinsic value of a species as a fuel [37]. Therefore, FVI was calculated using the modified formula (Equation (1)), ignoring the moisture content.

The density of the energy as received $\left(E_{d}\right)$ was assessed by utilising the LHV as received and the bulk density of each tree component, according to (2):

$$
E_{d}=\frac{1}{3600} \times q_{p, n e t, a r} \times B D_{a r}
$$

where $E_{d}$ represents the energy density of the biofuel as received ( $\mathrm{MWh} \cdot \mathrm{m}^{-3}$ of bulk density), $q_{p, n e t, a r}$ represents the LHV as received $\left(\mathrm{MJ} \cdot \mathrm{kg}^{-1}\right)$, the bulk density, i.e., volume weight of the biofuel as received is given by $B D_{a r}\left(\mathrm{~kg} \cdot \mathrm{m}^{-3}\right.$ bulk volume), and 1/3600 represents the conversion factor for the energy units (MJ to MWh).

For the calculations of energy density after harvesting we used for branches and needles of maritime pine, an average bulk density of $285 \mathrm{Kg} \cdot \mathrm{m}^{-3}$ [38] for green bundles of logging residues. For wood stem and top of tree, wood density was used in the calculations.

\subsubsection{Determination of Ash Elemental Metals}

After the combustion of biofuel, following CEN/TS 14775:2004, the ash elemental metals-iron $(F e)$, aluminium $(A l)$, arsenic $(A s)$, cadmium $(C d)$, lead $(P b)$, cobalt $(C o)$, copper $(C u)$, chromium $(C r)$, manganese $(\mathrm{Mn})$, zinc $(\mathrm{Zn})$ and nickel $(\mathrm{Ni})$ - were measured by following the standard CEN/TS 15290:2006 Solid Biofuels-Determination of major elements, and by following the standard CEN/TS 15297:2006 Solid biofuels-Determination of minor elements.

The detection of the major elements ( $F e$ and $A l$ ) was performed by using flame atomic absorption spectrometry, known as FAAS, and the detection of the minor elements $(\mathrm{As}, \mathrm{Pb}, \mathrm{Cd}, \mathrm{Co}, \mathrm{Cr}, \mathrm{Cu}, \mathrm{Mn}$, $\mathrm{Zn}$ and $\mathrm{Ni}$ ) was carried out by means of graphite furnace atomic absorption spectroscopy, known as 
GF-AAS, after the ash digestion with nitric acid- $\mathrm{HNO}_{3}(65 \%)$, hydrofluoric acid- $\mathrm{HF}(40 \%)$, hydrogen peroxide $-\mathrm{H}_{2} \mathrm{O}_{2}(30 \%)$ and boric acid- $\mathrm{H}_{3} \mathrm{BO}_{3}(4 \%)$.

It should be noted, as concluded by [23], that the method used in the assessment of major and minor ash-forming elements in solid biofuels can give values that are significantly different.

\section{Results and Discussion}

\subsection{Pine Stand Characteristics}

The biometrical characteristics of pine stands where the biomass samples were collected for fuel and ash analysis are presented in Table 1.

Table 1. Descriptive statistics of 16 maritime pine plots.

\begin{tabular}{|c|c|c|c|c|c|c|c|}
\hline $\begin{array}{c}\text { Stands Plots } \\
\text { (n) }\end{array}$ & $\begin{array}{c}N \\
\left(\text { trees } \cdot \mathrm{ha}^{-1}\right)\end{array}$ & $\begin{array}{c}T \\
\text { (year) }\end{array}$ & $\begin{array}{l}d_{b h} \\
(\mathrm{~cm})\end{array}$ & $\begin{array}{c}H \\
(\mathrm{~m})\end{array}$ & $\begin{array}{c}B A \\
\left(\mathrm{~m}^{2} \cdot \mathrm{ha}^{-1}\right)\end{array}$ & $\begin{array}{c}S I \\
(\mathrm{~m})\end{array}$ & $\begin{array}{c}B_{d r y} \\
\left(\text { ton } \cdot \mathbf{h a}^{-1} \text { ) }\right.\end{array}$ \\
\hline 1 & 700 & 52 & 39.8 & 21.3 & 59.2 & 19 & 420.2 \\
\hline 2 & 800 & 40 & 28.6 & 19.4 & 55.8 & 24 & 260.9 \\
\hline 3 & 600 & 51 & 31.5 & 19.9 & 49.7 & 19 & 232.5 \\
\hline 4 & 600 & 44 & 32.0 & 19.6 & 50.5 & 20 & 231.1 \\
\hline 5 & 600 & 42 & 29.5 & 18.6 & 43.4 & 18 & 193.1 \\
\hline 6 & 600 & 54 & 29.4 & 19.1 & 43.4 & 19 & 194.2 \\
\hline 7 & 620 & 26 & 23.6 & 14.9 & 30.9 & 20 & 123.4 \\
\hline 8 & 460 & 39 & 30.6 & 13.6 & 38.6 & 15 & 158.1 \\
\hline 9 & 900 & 20 & 14.1 & 10.6 & 16.7 & 16 & 58.4 \\
\hline 10 & 620 & 20 & 15.0 & 9.0 & 15.4 & 14 & 53.2 \\
\hline 11 & 460 & 51 & 27.4 & 20.6 & 29.3 & 19 & 132.7 \\
\hline 12 & 2020 & 27 & 13.3 & 12.9 & 30.1 & 15 & 106.3 \\
\hline 13 & 460 & 60 & 33.9 & 22.8 & 66.9 & 25 & 406.2 \\
\hline 14 & 520 & 48 & 24.0 & 16.5 & 43.1 & 20 & 203.7 \\
\hline 15 & 980 & 26 & 17.9 & 11.2 & 36.7 & 18 & 140.1 \\
\hline 16 & 720 & 35 & 22.0 & 15.8 & 31.0 & 20 & 130.1 \\
\hline Mean & 729 & 40 & 26 & 17 & 40 & 19 & 190 \\
\hline Min & 460 & 20 & 13 & 9 & 15 & 14 & 53 \\
\hline Max & 2020 & 60 & 40 & 23 & 67 & 25 & 420 \\
\hline SD & 375.6 & 12.7 & 7.7 & 4.2 & 14.4 & 3.0 & 105.3 \\
\hline
\end{tabular}

Where $N$ is the number of stems ha ${ }^{-1} ; t$ is the stand mean age; $h$ is the mean height; $d_{b h}$ is the mean diameter at breast height; $B A$ is the basal area; $S I$ is the site index and $B_{d r y}$ represents the dry biomass (ton $\cdot \mathrm{ha}^{-1}$ ).

The maritime pine stands are pure self-thinned and even-aged, with ages ranging between 20 and 60 years. The younger plants with a stand mean age of 20 years (plots 9 and 10) showed, as expected, lower heights of $9 \mathrm{~m}$ and $10.6 \mathrm{~m}$, lower $d_{b h}$ of $14.1 \mathrm{~cm}$ and $15 \mathrm{~cm}$, lower basal area and lower biomass dry estimates of $58.4 \mathrm{ton} \cdot \mathrm{ha}^{-1}$ and $53.2 \mathrm{ton} \cdot \mathrm{ha}^{-1}$, respectively. The maximum tree density was found for plot 12 , with an average age of 27 years and $106.3 \mathrm{ton} \cdot \mathrm{ha}^{-1}$ biomass dry yield.

Plots 1 and 13 corresponded to 52 and 60-year-old trees, with dry biomass yields of 420.2 ton $\cdot$ ha $^{-1}$ and 406.2 ton $\cdot \mathrm{ha}^{-1}$, respectively. The highest site index (SI) of 25 was found for plot 13 , with average 60-year-old trees, and $S I=20$ was found for plots 4,7 and 14 with tree densities of 600,620 and 520 trees ha $^{-1}$ and average ages 44,26 and 48 years, respectively. Plot 7 showed a peculiar biomass potential, given its relatively high SI of 29 , good biomass productivity taking into account its young age, and its relatively small diameter $(23.6 \mathrm{~cm})$.

\subsection{Proximate Analysis and Physical Properties}

The final proximate analysis, moisture content and density of woody biomass of pine tree components are shown in Table 2. 
Table 2. Proximate analysis and basic density of maritime pine woody biomass elements.

\begin{tabular}{|c|c|c|c|c|}
\hline & \multicolumn{3}{|c|}{ Proximate Analysis (wt \%) } & \multirow{2}{*}{$D_{d b}\left(\mathrm{Kg} \cdot \mathrm{m}^{-3}\right)$} \\
\hline & Ash & VM & FC & \\
\hline Wood stem & $0.22( \pm 0.0011)$ & $85.7( \pm 0.0096)$ & $14.0( \pm 0.0095)$ & $476.4( \pm 0.039)$ \\
\hline Top & $0.24( \pm 0.0035)$ & $84.2( \pm 0.0031)$ & $15.6( \pm 0.0058)$ & $332.7( \pm 0.040)$ \\
\hline Branches & $1.00( \pm 0.0023)$ & $80.8( \pm 0.0061)$ & $18.2( \pm 0.0058)$ & $419.6( \pm 0.047)$ \\
\hline Needles & $1.97( \pm 0.0022)$ & $79.4( \pm 0.0065)$ & $18.7( \pm 0.0074)$ & $358.6( \pm 0.050)$ \\
\hline
\end{tabular}

Where the proximate and ultimate analyses are in terms of wt. \% dry biomass basis. The ash is represented as percentage (\%), VM is the Volatile Matter (\%), FC is the Fixed Carbon (\%), wt \% is the moisture content wet basis $(\%)$ and the basic density $\left(\mathrm{kg} \cdot \mathrm{m}^{-3}\right)$ is $D_{d b}$. Numbers in parentheses are the standard deviations.

Ash content ranged from 0.22 to $1.97 \%$ for stem and needles, respectively. These are favourable values, insofar that they are lower than the data quoted by the literature. For example, in [39], values of $3 \%$ were found for maritime pine foliage, and in [40], values between 1.16 and $2.55 \%$ are shown for Pinus pinaster dead meddles in Mediterranean countries [40].

In a study comparing the calorific value and chemical composition of maritime pine woody biomass infected and not infected with pine nematode [41], the average ash weight percent was provided as $0.66 \%$, and ranged between $0.25 \%$ and $1.04 \%$ for healthy maritime pine wood [41].

In [42], lower values are reported for Spain, ranging between 0.31 and $0.69 \%$ for pine needles, with values for branches ranging from 0.05 to $0.026 \%$. In other work [43], values between 0.71 and $1.04 \%$ are shown for pine aboveground biomass ash, and in $[41,44], 0.25 \%$ and $0.2 \%$ were the values found, respectively, for Pinus pinaster wood samples in Portugal.

Other references, such as [45], give the ash weight percentage as $0.6 \%$, and in [46], ash amounts of $1.3 \%$ were obtained for maritime pine shells. The digital database of the Biomass Energy Foundation (BEF) [47] reports ash values of $1.31 \%$ for yellow pine and $0.29 \%$ for ponderosa pine. In [22], weight percent data of $2.7 \%$ for pine chips and $3.5 \%$ for ash was reported for a set of 28 woody biomass species.

For the Fixed Carbon (FC) in [45], values around 26\% were obtained for maritime pine bark biomass, while in [46], values of $26 \%$ were reported for pine shells, and on the BEF digital database [47], FC reaches around $26.1 \%$ for pine needles. As a comparison, Ponderosa pine has FC of about $17 \%$. In [22], values of $21.6 \%$ for pine chips, $14 \%$ for stem, $15.6 \%$ for top, $18.2 \%$ for branches and $18.7 \%$ for needles were found.

Volatile matter (VM) percentage for maritime pine woody biomass reaches $63.7 \%$, according to [48] and 59\% for pine shells, according to [46], and $72 \%$ for pine needles. In [22] values of $72.4 \%$ for pine chips and $78 \%$ for wood residues were reported for a set of 28 wood species. For maritime pine, VM for stems $(85.7 \%)$, tops $(84.2 \%)$, branches $(80.8 \%)$ and needles $(79.4 \%)$ are a bit higher than the cited values for other pine species. VM for ponderosa pine biomass reaches $82.5 \%$.

The basic densities $\left(D_{d b}\right)$ obtained for maritime pine biomass tree components (Table 2) were $476 \mathrm{~kg} \cdot \mathrm{m}^{-3}, 419 \mathrm{~kg} \cdot \mathrm{m}^{-3}, 358.6 \mathrm{~kg} \cdot \mathrm{m}^{-3}$ and $332.7 \mathrm{~kg} \cdot \mathrm{m}^{-3}$, for stem, branches, tops and needles, respectively. Our results are in the range of the average values reported in the literature for P. pinaster biomass tree components and total AGB [49-51].

\subsection{Ultimate Analysis}

Ultimate analysis results for tree biomass components of maritime pine are shown in Table 3.

Elementary carbon varied slightly, with values of $46.5 \%, 48.4 \%, 48.6 \%$, and $48.2 \%$ for stem, top, branches and needles, respectively.

As for similar studies, in [45], an elementary carbon value of $46.9 \%$ was also obtained for maritime pine woody biomass. In [46], a similar value of $47.8 \%$ was reported for maritime pine shells, and in [22], values such as $44.3 \%$ for stem, $50.8 \%$ for branches and $47.5 \%$ for needles are given for maritime pine biomass components. In [41], an average of $49.32 \%$ elementary carbon is reported in Portuguese 
maritime pine wood samples. Finally, in [42], slightly higher values are given for maritime pine in NW Spain, ranging from $49.40 \%$ to $55.23 \%$ for needles, and from $48.33 \%$ to $54.92 \%$, for branches.

Table 3. Ultimate analysis maritime pine woody biomass components.

\begin{tabular}{cccccc}
\hline & \multicolumn{5}{c}{ Ultimate Analysis (wt. \%) } \\
\cline { 2 - 6 } & $\mathbf{C}$ & $\mathbf{H}$ & $\mathbf{O}$ & $\mathbf{N}$ & S \\
\hline Wood Stem & $46.5( \pm 0.107)$ & $6.7( \pm 0.082)$ & $46.4( \pm 0.026)$ & $0.13( \pm 0.025)$ & $0.029( \pm 0.005)$ \\
Top & $48.4( \pm 0.120)$ & $6.8( \pm 0.070)$ & $43.8( \pm 0.060)$ & $0.21( \pm 0.010)$ & $0.050( \pm 0.002)$ \\
Branches & $48.6( \pm 0.319)$ & $6.8( \pm 0.050)$ & $43.3( \pm 0.408)$ & $0.28( \pm 0.013)$ & $0.032( \pm 0.010)$ \\
Needles & $48.2( \pm 0.225)$ & $6.9( \pm 0.063)$ & $42.1( \pm 0.184)$ & $0.74( \pm 0.063)$ & $0.86( \pm 0.026)$ \\
\hline
\end{tabular}

Where ultimate analyses are in terms of wt. \% dry biomass basis. Numbers in parentheses represent the Standard Deviations.

Elementary carbon from the BEF digital database [47] was $49.3 \%$ and $52.6 \%$ for yellow pine and ponderosa pine woody biomass, respectively. In [22], values of $52.8 \%$ of elementary carbon for pine wood species and an average of 52\% elementary carbon are also reported for a set of 28 woody biomass species.

The elementary hydrogen weight contents achieved were $6.7 \%, 6.8 \%, 6.8 \%$ and $6.9 \%$ for maritime pine stem, top, branches and needles, respectively. These values are of the same order of magnitude as those quoted in literature. Indeed, in [45], 6.3\% hydrogen for maritime pine wood was found, while in [52], an amount of $6.1 \%$ hydrogen was reported in pine woody biomass, with an average of $5.4 \%$ for a set of 28 woody biomass species. In [41], an average value of $6.3 \%$ was reported for maritime pine woody biomass, with values ranging between $6 \%$ and $6.78 \%$, while in [46], a hydrogen amount of $4.3 \%$ was provided, and the digital database of BEF [47] provided $6 \%$ and $7 \%$ for the hydrogen amounts in ponderosa pine and yellow pine, respectively.

The elementary oxygen weight percentage values, although lower than elementary carbon, are higher than those quoted by the literature. Indeed, the authors in [45] reached an amount of $45.7 \%$ for maritime pine woody biomass. In [52], the authors determined $41 \%$ for pine chips, and the digital database of BEF [47] provided information of the order of magnitude of $44.36 \%$ of oxygen for Ponderosa pine and $40.1 \%$ for yellow pine. In [46], 32.4\% was found for oxygen percentage in maritime pine shells. The research in [41], on maritime pine, was that with values of elementary oxygen weight amounts closest to those obtained in this work, with an average of $42.62 \%$, ranging between $38.69 \%$ and $45.30 \%$.

The sulphur content was under the $0.1 \%$ threshold fixed in [53] for minimising sulphur-related risk of corrosion in combustion of biomass in boilers, which is comparable to the mean values of woody fuels. This elementary sulphur amount is slightly higher in [45] for maritime pine crown, bark and wood. Table 4 shows the calculated atomic ratios $(\mathrm{O} / \mathrm{C})$ and $(\mathrm{H} / \mathrm{C})$, which have values in the usual range for biomass [54].

Table 4. Ratios $\mathrm{O} / \mathrm{C}$ and $\mathrm{H} / \mathrm{C}$ for maritime pine biomass components.

\begin{tabular}{ccc}
\hline & O/C (Atomic) & H/C (Atomic) \\
\hline Wood stem & 0.75 & 1.73 \\
Top & 0.68 & 1.69 \\
Branches & 0.67 & 1.68 \\
Needles & 0.66 & 1.72 \\
\hline
\end{tabular}

\subsection{Higher and Lower Heating Values}

Higher and lower heating values (HHV and LHV) of biomass tree components of maritime pine, as well as the basic density in dry basis $\left(D_{d b}\right)$, of fuelwood are presented in Table 5 and Figure 1. 
In Table 5, the HHV is the Higher Heating Value (MJ. $\mathrm{kg}^{-1}$ at dry basis) and basic density. The numbers in parentheses give the Standard Deviations.

Table 5. Higher and lower heating values (HHV and LHV) and basic density of maritime pine biomass components.

\begin{tabular}{ccc}
\hline & HHV $\left(\mathbf{M J} \cdot \mathbf{k g}^{-\mathbf{1}}\right)$ & $\left.\boldsymbol{D}_{d b} \mathbf{( K g} \cdot \mathbf{m}^{-3}\right)$ \\
\hline Wood stem & $21.60( \pm 0.541)$ & 476.4 \\
Top & $20.65( \pm 0.60)$ & 332.7 \\
Branches & $20.92( \pm 0.555)$ & 419.6 \\
Needles & $21.61( \pm 0.492)$ & 358.6 \\
\hline
\end{tabular}

The HHV analysed for stem, top, branches and needles resulted in values of $21.6 \mathrm{MJ} \cdot \mathrm{kg}^{-1}$, $20.65 \mathrm{MJ} \cdot \mathrm{kg}^{-1}, 20.92 \mathrm{MJ} \cdot \mathrm{kg}^{-1}$ and $21.61 \mathrm{MJ} \cdot \mathrm{kg}^{-1}$, respectively. Similar HHV values are presented in [42] for maritime pine biomass tree components in NW Spain for needles $\left(20.42 \mathrm{MJ} \cdot \mathrm{kg}^{-1}\right.$ to $\left.21.7 \mathrm{MJ} \cdot \mathrm{kg}^{-1}\right)$ for thin branches (20.18 MJ $\cdot \mathrm{kg}^{-1}$ to $21.40 \mathrm{MJ} \cdot \mathrm{kg}^{-1}$ ) and for thick branches $\left(19.09 \mathrm{MJ} \cdot \mathrm{kg}^{-1}\right.$ and $20.26 \mathrm{MJ} \cdot \mathrm{kg}^{-1}$ ), and the conclusions reached in [41] present HHV values for woody maritime pine in Central Portugal ranging between $19.48 \mathrm{MJ} \cdot \mathrm{kg}^{-1}$ and $20.69 \mathrm{MJ} \cdot \mathrm{kg}^{-1}$.

Data compiled in [55] for maritime pine showed a HHV of $21.2 \mathrm{MJ} \cdot \mathrm{kg}^{-1}$ for needles in France, and $21.49 \mathrm{MJ} \cdot \mathrm{kg}^{-1}$ and $21.3 \mathrm{MJ} \cdot \mathrm{kg}^{-1}$ for live and dead needles in Spain, respectively; for dead twigs with dimensions 0-2 mm, 2-6 mm and $6.25 \mathrm{~mm}, 22.071 \mathrm{MJ} \cdot \mathrm{kg}^{-1}, 21.37 \mathrm{MJ} \cdot \mathrm{kg}^{-1}$ and $21.03 \mathrm{MJ} \cdot \mathrm{kg}^{-1}$, respectively; for dead cones, $20.7 \mathrm{MJ} \cdot \mathrm{kg}^{-1}$. However, in [45], lower calorific values of $19 \mathrm{MJ} \cdot \mathrm{kg}^{-1}$ were reported for maritime pine woody biomass, as well as $19.8 \mathrm{MJ} \cdot \mathrm{kg}^{-1}$ for maritime pine bark and around $20 \mathrm{MJ} \cdot \mathrm{kg}^{-1}$ for maritime pine crown biomass. Also, the HHV value for maritime pine cones is assessed in [46] and is equal to $18.82 \mathrm{MJ} \cdot \mathrm{kg}^{-1}$.

Comparing the achieved values with other pine species, these are in the same range. In [55], for Aleppo pine dead needles and dead twigs, values of HHV of $22.08 \mathrm{MJ} \cdot \mathrm{kg}^{-1}$ and $20.6 \mathrm{MJ} \cdot \mathrm{kg}^{-1}$ were reported, respectively, in Castilla y León. For stone pine dead needles and twigs, an HHV of $21.8 \mathrm{MJ} \cdot \mathrm{kg}^{-1}$ was reported, and for cones, an $\mathrm{HHV}$ of $20.1 \mathrm{MJ} \cdot \mathrm{kg}^{-1}$. For Monterey pine live and dead needles, HHVs of $21.4 \mathrm{MJ} \cdot \mathrm{kg}^{-1}$ and $22.5 \mathrm{MJ} \cdot \mathrm{kg}^{-1}$, respectively, were reported, and for dead cones an HHV of $20.1 \mathrm{MJ} \cdot \mathrm{kg}^{-1}$.

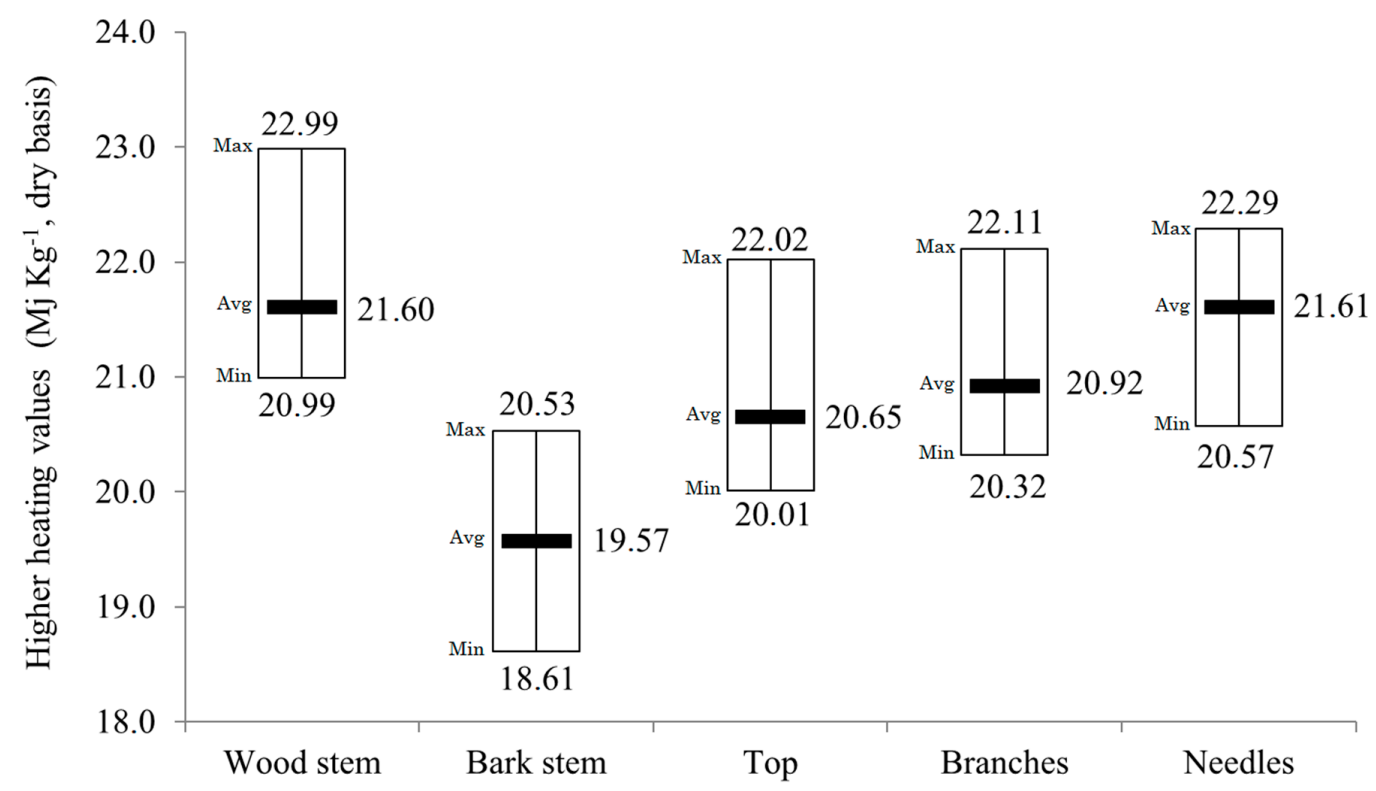

Figure 1. Average higher heating values of maritime pine woody biomass (Max, Min and Avg stand for Maximum, Minimum and Average). 


\subsection{Fuelwood Value Index (FVI) and Energy Density $\left(E_{d}\right)$}

Fuelwood value index is a valid parameter for evaluating quality, insofar as woody biomasses with higher FVI exhibit good fuel qualities. Several studies point clearly to that conclusion. Indeed, from its very definition, FVI for woody biomasses should be correlated with high energy content, high wood density, and low ash and moisture content. Consequently, FVI has even been considered as a standard parameter for identifying suitable tree species for fuelwood production [56,57].

The results of FVI for the four tree components of the maritime pine woody biomass-stem, top, branches and needles-are shown in Table 6, wherein it can be observed that there is a significant decrease from stem (4658), to top (2861), to branches (880), to needles (394).

Table 6. Higher and lower heating values (HHV and LHV), ash maritime pine woody biomass Fuelwood value index (FVI), and energy density $\left(E_{d}\right)$.

\begin{tabular}{cccccc}
\hline & HHV $\left(\mathbf{M J} \cdot \mathbf{k g}^{-\mathbf{1}}\right)$ & $\boldsymbol{D}_{\boldsymbol{d} b} \mathbf{( \mathbf { k g } \cdot \mathbf { m } ^ { - 3 } )}$ & Ash (\%) & FVI & $\boldsymbol{E}_{\boldsymbol{d}}\left(\mathrm{GJ} \cdot \mathbf{m}^{-\mathbf{3}}\right)$ \\
\hline Wood stem & 21.60 & 476.4 & 0.22 & 4658.0 & 8.99 \\
Top & 20.65 & 332.7 & 0.24 & 2861.8 & 6.31 \\
Branches & 20.92 & 419.6 & 1.00 & 880.4 & 2.08 \\
Needles & 21.61 & 358.6 & 1.97 & 394.2 & 2.06 \\
\hline
\end{tabular}

By comparing the calculated FVI for maritime pine biomass tree components with other species, it is possible to obtain a better picture of the quality of maritime pine fuelwood; Ref. [56] presents, in India, a FVI ranging between 792.6 for Quercus serrata and 1109.7 for Castanopsis indica (Chinquapin). In [57], a longitudinal study of FVI with Melia dubia, an Indian fast growing hardwood, was conducted, showing that this parameter increases with age from 1 to 5 years of age, with values varying from 1540 to 4125 [57]. Also, ref. [37] reported experimental work with a set of small branch cuttings from 25 Indian woody biomass species with values of FVI ranging between 343 and 1434, compared with the value of FVI of 880.4 for maritime pine branches obtained in this work.

Energy density $\left(E_{d}\right)$, as mentioned above, is an important variable for addressing the costs of storage and transport and biomass, which became cheaper and more efficient with higher energy density.

In Table 6, it can be seen that energy density exhibits the same variability as FVI insofar that it also decreases from woody stem with $8.99 \mathrm{GJ} \cdot \mathrm{m}^{-3}$, top with $6.31 \mathrm{GJ} \cdot \mathrm{m}^{-3}$, branches with $2.08 \mathrm{GJ} \cdot \mathrm{m}^{-3}$ and needles with $2.06 \mathrm{GJ} \cdot \mathrm{m}^{-3}$. Ash amount increases in the maritime pine biomass components with a decrease of FVI and $E_{d}$.

The $E_{d}$ values found in this work for maritime pine biomass components (Table 6) compare well with values cited in the literature, such as: grass in high pressed bales $\left(2.74 \mathrm{GJ} \cdot \mathrm{m}^{-3}\right)$, woodchips of softwood $\left(2.8 \mathrm{GJ} \cdot \mathrm{m}^{-3}\right)$, straw (winter wheat) $\left(1.74 \mathrm{GJ} \cdot \mathrm{m}^{-3}\right)$, and triticale (cereals) $\left(1.92 \mathrm{GJ} \cdot \mathrm{m}^{-3}\right)$. If this biomass is processed into pellets for household usage, the bulk density is higher, $\approx 550-650 \mathrm{~kg} \cdot \mathrm{m}^{3}$ [58,59], so the energy density also increases, e.g., from 8.9 to $11.5 \mathrm{GJ} \cdot \mathrm{m}^{-3}$ [58].

Densification of biomass through chipping, bundling, torrefaction or pelletising maximises $E_{d}$ and FVI. Small branches and leaves need greater space for transporting and storing, so the low energy density is an evident problem associated with this wood fuel. The compression into bundles varies according to the type of biomass residues and to the type of machinery utilised [60-62].

\subsection{Ash Elemental Metals}

The analysis results for heavy metal- $\mathrm{Fe}, \mathrm{Al}, \mathrm{As}, \mathrm{Cd}, \mathrm{Pb}, \mathrm{Co}, \mathrm{Cu}, \mathrm{Cr}, \mathrm{Mn}, \mathrm{Zn}$, and $\mathrm{Ni}-$ concentrations present in ash $\left(\mathrm{mg} \cdot \mathrm{kg}^{-1}\right)$ generated in the combustion process are presented in Table 7 . These results are then compared to the limit values instituted by legislation on the utilisation ash as a fertiliser in forestry and agriculture in several European countries [63], such as Denmark, Finland, UK, Sweden and Austria. The presently existing Portuguese legislation, with restraining limits for such types of elements, 
applies to the sludge from water treatment plants, which is used for agriculture, as established in the Decree-Law n ${ }^{\circ} 118 / 2006$ [64].

Table 7. Concentrations $\left(\mathrm{mg} \cdot \mathrm{kg}^{-1}\right.$ ) of heavy metals in ash of Pinus pinaster and limit values in European countries' legislation.

\begin{tabular}{|c|c|c|c|c|c|c|c|c|c|c|c|}
\hline Pinus pinaster & $\mathrm{Fe}$ & $A l$ & As & $C d$ & $P b$ & Co & $C u$ & $\mathrm{Cr}$ & $M n$ & $Z n$ & $\mathrm{Ni}$ \\
\hline Wood stem & $29,375.0$ & 5884.4 & 3.8 & 0.9 & 13.4 & 17.1 & 926.3 & 109.4 & 9750.0 & 1250.0 & 37.5 \\
\hline Bark stem & 9794.0 & 8231.2 & 3.0 & 2.1 & 0.4 & 26.3 & 85.1 & 8.5 & 7239.0 & 1618.1 & 21.3 \\
\hline Top & 4897.2 & $10,980.2$ & 5.7 & 9.7 & 10.2 & 9.0 & 791.2 & 10.8 & 8605.1 & 2863.7 & 21.0 \\
\hline Branches & 7522.3 & 8782.3 & 3.8 & 4.7 & 3.9 & 18.7 & 333.7 & 88.8 & 7346.8 & 2557.6 & 20.1 \\
\hline Needles & 7758.9 & 3253.7 & 2.4 & 0.7 & 1.5 & 5.6 & 43.2 & 113.5 & $21,623.2$ & 737.7 & 25.4 \\
\hline \multicolumn{12}{|c|}{ Country (application) } \\
\hline \multirow{2}{*}{\multicolumn{3}{|c|}{$\begin{array}{c}\text { Portugal (Agriculture) * } \\
\text { Denmark (Agriculture/Forestry) }\end{array}$}} & & 20 & 750 & & 1000 & 1000 & & 2500 & 300 \\
\hline & & & & 15 & 120 & & & 100 & & & 30 \\
\hline \multicolumn{3}{|c|}{ Finland (Agriculture) } & 25 & 1.5 & 100 & & 600 & 300 & & 1500 & 100 \\
\hline \multicolumn{3}{|c|}{ Finland (Forestry) } & 30 & 17.5 & 150 & & 700 & 300 & & 4500 & 150 \\
\hline \multicolumn{3}{|c|}{ Sweden (Forestry) } & 30 & 30 & 300 & & 400 & 100 & & 7000 & 300 \\
\hline \multicolumn{3}{|c|}{ Austria (Field and grassland) } & 20 & 8 & 100 & 100 & 250 & 250 & & 1500 & 100 \\
\hline \multicolumn{3}{|c|}{ Spain (Soils with $p_{h}<7$ ) } & & 20 & 750 & & 1000 & 1000 & & 2500 & 300 \\
\hline \multicolumn{3}{|c|}{ Spain (Soils with $p_{h}>7$ ) } & & 40 & 1200 & & 1750 & 1500 & & 4000 & 400 \\
\hline
\end{tabular}

${ }^{*}$ Limit values of concentration of heavy metals in sludge from water treatment plants.

The measured contents of ash $\mathrm{Fe}, \mathrm{As}, \mathrm{Al}, \mathrm{Pb}, \mathrm{Cd}, \mathrm{Cu}, \mathrm{Co}, \mathrm{Cr}, \mathrm{Mn}, \mathrm{Ni}$, and $\mathrm{Zn}$ are close to the usual ranges commonly found in the ash of biomass tree components (wood, bark, leaves, etc.) for such elements, as conveyed in many research publications [12,65-70] such as in the most popular wood and ash properties databases already discussed previously.

Some exceptions were observed in $\mathrm{Al}$ content for pine needles, values for which were lower than the reported values in the literature. In maritime pine wood stem, the $C u$ content was higher than that mentioned in the literature, but in [71], an even higher content value for this parameter was presented in P. pinaster measured in NW Spain.

The results of the assessed values happened to be comfortably below the limits instituted by the current Portuguese legislation for all of the studied elements (except for $\mathrm{Zn}$ content in pine branches and tops), and also below the limits of the majority of the legislations of several European countries, as can be observed in Table 7. However, some of the observed values in biomass ash would not meet the most restrictive limits enforced by some Central and North European countries for $\mathrm{Cu}\left(<250 \mathrm{mg} \cdot \mathrm{kg}^{-1}\right)$, $\mathrm{Zn}\left(<1500 \mathrm{mg} \cdot \mathrm{kg}^{-1}\right), \mathrm{Cd}\left(<1.5 \mathrm{mg} \cdot \mathrm{kg}^{-1}\right), \mathrm{Cr}\left(<100 \mathrm{mg} \cdot \mathrm{kg}^{-1}\right)$ and $\mathrm{Ni}\left(<1500 \mathrm{mg} \cdot \mathrm{kg}^{-1}\right)$, and could therefore potentially induce volatilisation problems in thermo-chemical conversion, requiring special filtering systems, or in soil contamination.

Despite the potential soil contamination by some elements present in the ash, given their low concentration, especially in the ash-slag, from the results of this work, the constraints placed on the use of maritime pine biomass ash as fertiliser on soil should be minimal. However, the authors in [67] call attention to the fact that, in cases in which an application of ash is made in large quantities, even if the typical trace element contents that are found in the ash of forest residues do not present any real risk, as long as the fly ash is not utilised, the variation of $\mathrm{Cu}, \mathrm{Ni}$ and $\mathrm{Zn}$ in the bottom ash represents a risk of surpassing the allowed thresholds [67].

Even though the application of ash has an effect on the surrounding environment, it is still safe to apply ash up to $10 \mathrm{t} \cdot \mathrm{ha}^{-1}$ from ordinary boilers, since the results in heavy metal soil levels are still 2 levels below the United States Environmental Protection Agency (USEPA) guidelines. However, the environmental impact should still be a target of exhaustive research, as highlighted in [52], given that long-term study on the ecological impact of the ash is fairly limited [56]. 


\section{Conclusions}

Biomass samples of maritime pine (Pinus pinaster Aiton.) species were assessed with respect to the contents of carbon, nitrogen, hydrogen, oxygen and sulphur, determined by ultimate analysis and by the ash content of volatile matter and fixed carbon, as determined by proximate analyses. The calorific values were measured, and the Energy Density and the Fuelwood Value Index of biomass tree components were calculated. The metal elements of the ash were measured and compared to the restricted values enforced by the legislation of several European countries on ash utilisation in forestry and agriculture as a fertiliser.

The high calorific value of biomass tree components (19.57 to $21.61 \mathrm{MJ} \cdot \mathrm{kg}^{-1}$ ) and calculated $E_{d}$ of 2.06 to $8.9 \mathrm{GJ} \cdot \mathrm{m}^{-3}$ reveal the considerable potential of this biomass to be utilised as an important source of energy. The FVI ranks, from higher to lower quality, the pine wood stem (4658) and top (2861.8) and pine needles (394.2).

The elemental analysis indicated that high amounts of carbon content (46.5 to $49.3 \%$ ) are stored in the biomass of pinewood components. Such information has an underlining significance for future studies that aim to quantify the importance of this species in the global cycle of carbon.

A phenomenon that typically occurs in the use of biomass in wood-fired power plants is the employment of ash from combustion. As for the chemical composition of the ash, the analysis indicated that the ash can be employed on forest or agricultural soils, since the analysis showed that the heavy metals were below the legal maximum allowable quantities. A reparation for the loss of nutrients could be achieved from the harvesting location by recycling ash as a soil improving agent or as a fertiliser, thus offering environmental and, in some cases, economic benefits.

Author Contributions: H.F.d.S.V. performed the writing and original draft preparation. A.M.R. performed parts of the literature review. R.G. handled the writing and editing of the manuscript and contributed with parts of the literature review. J.C.d.O.M. and L.J.R.N. supervised, revised and corrected the manuscript.

Funding: This work was supported by European Investment Funds by FEDER/COMPETE/POCI-Operational Competitiveness and Internationalisation Programme, under Project POCI-01-0145-FEDER-006958 and National Funds by FCT-Portuguese Foundation for Science and Technology, under the project UID/AGR/04033/2013 and by SFRH/PROTEC/49626/2009 grant provided to the first author. We thank Cristóvão Santos from Mechanical Department of the University of Trás-os-Montes and Alto Douro, where calorific analysis was done, and Rui Rocha from Leco laboratory for the assistance in elemental analysis. This work was also supported by Fundação para a Ciência e Tecnologia (FCT), under the project UID/EMS/00151/2013 C-MAST, with reference POCI-01-0145-FEDER-007718. This research was also funded by the following project: Centro-01-0145-FEDER-000017-EMaDeS-Energy, Materials and Sustainable Development, co-financed by the Portugal 2020 Program (PT 2020), comprised of the Regional Operational Program of the Center (CENTRO 2020) and the European Union through the European Regional Development Fund (ERDF).

Conflicts of Interest: The authors declare no conflicts of interest.

\section{References}

1. Dias, A.C.; Arroja, L. Environmental impacts of eucalypt and maritime pine wood production in Portugal. J. Clean. Prod. 2012, 37, 368-376. [CrossRef]

2. Viana, H.; Cohen, W.B.; Lopes, D.; Aranha, J. Assessment of forest biomass for use as energy. GIS-based analysis of geographical availability and locations of wood-fired power plants in Portugal. Appl. Energy 2010, 87, 2551-2560. [CrossRef]

3. Gómez-González, S.; Ojeda, F.; Fernandes, P.M. Portugal and Chile: Longing for sustainable forestry while rising from the ashes. Environ. Sci. Policy 2018, 81, 104-107. [CrossRef]

4. Parente, J.; Pereira, M.G.; Amraoui, M.; Tedim, F. Negligent and intentional fires in Portugal: Spatial distribution characterization. Sci. Total Environ. 2018, 624, 424-437. [CrossRef] [PubMed]

5. Sá, A.C.L.; Turkman, M.A.A.; Pereira, J.M.C. Exploring fire incidence in Portugal using generalized additive models for location, scale and shape (GAMLSS). Model. Earth Syst. Environ. 2018, 4, 199-220. [CrossRef]

6. Godina, R.; Nunes, L.J.R.; Santos, F.M.B.C.; Matias, J.C.O. Logistics cost analysis between wood pellets and torrefied Biomass Pellets: The case of Portugal. In Proceedings of the 2018 7th International Conference on Industrial Technology and Management (ICITM), Oxford, UK, 7-9 March 2018; pp. 284-287. 
7. Ribeiro, J.M.C.; Godina, R.; de Oliveira Matias, J.C.; Nunes, L.J.R. Future Perspectives of Biomass Torrefaction: Review of the Current State-Of-The-Art and Research Development. Sustainability 2018, 10, 2323. [CrossRef]

8. Alén, R. Structure and chemical composition of wood. In Forest Products Chemistry; Stenius, P., Ed.; Gummerus Printing: Jyväskylä, Finland, 2000; pp. 11-57.

9. Kilpeläinen, A.; Peltola, H.; Ryyppö, A.; Sauvala, K.; Laitinen, K.; Kellomäki, S. Wood properties of Scots pines (Pinus sylvestris) grown at elevated temperature and carbon dioxide concentration. Tree Physiol. 2003, 23, 889-897. [CrossRef] [PubMed]

10. Viana, H.; Vega-Nieva, D.J.; Ortiz Torres, L.; Lousada, J.; Aranha, J. Fuel characterization and biomass combustion properties of selected native woody shrub species from central Portugal and NW Spain. Fuel 2012, 102, 737-745. [CrossRef]

11. Sjostrom, E. Wood Chemistry: Fundamentals and Applications; Elsevier: New York, NY, USA, 2013; ISBN 978-0-08-092589-9.

12. Saarela, K.E.; Harju, L.; Rajander, J.; Lill, J.O.; Heselius, S.J.; Lindroos, A.; Mattsson, K. Elemental analyses of pine bark and wood in an environmental study. Sci. Total Environ. 2005, 343, 231-241. [CrossRef] [PubMed]

13. Vassilev, S.V.; Baxter, D.; Andersen, L.K.; Vassileva, C.G.; Morgan, T.J. An overview of the organic and inorganic phase composition of biomass. Fuel 2012, 94, 1-33. [CrossRef]

14. Vassilev, S.V.; Baxter, D.; Andersen, L.K.; Vassileva, C.G. An overview of the composition and application of biomass ash. Part 1. Phase-mineral and chemical composition and classification. Fuel 2013, 105, 40-76. [CrossRef]

15. Nunes, L.J.R.; Matias, J.C.O.; Catalão, J.P.S. A review on torrefied biomass pellets as a sustainable alternative to coal in power generation. Renew. Sustain. Energy Rev. 2014, 40, 153-160. [CrossRef]

16. Sarvaramini, A.; Assima, G.P.; Larachi, F. Dry torrefaction of biomass-Torrefied products and torrefaction kinetics using the distributed activation energy model. Chem. Eng. J. 2013, 229, 498-507. [CrossRef]

17. Van der Stelt, M.J.C.; Gerhauser, H.; Kiel, J.H.A.; Ptasinski, K.J. Biomass upgrading by torrefaction for the production of biofuels: A review. Biomass Bioenergy 2011, 35, 3748-3762. [CrossRef]

18. Rodrigues, A.; Loureiro, L.; Nunes, L.J.R. Torrefaction of woody biomasses from poplar SRC and Portuguese roundwood: Properties of torrefied products. Biomass Bioenergy 2018, 108, 55-65. [CrossRef]

19. Grigiante, M.; Brighenti, M.; Antolini, D. A generalized activation energy equation for torrefaction of hardwood biomasses based on isoconversional methods. Renew. Energy 2016, 99, 1318-1326. [CrossRef]

20. Núñez-Regueira, L.; Proupín-Castiñeiras, J.; Rodríguez-Añón, J.A. Design of an experimental procedure for energy evaluation from biomass. Thermochim. Acta 2004, 420, 29-31. [CrossRef]

21. Moya, R.; Tenorio, C. Fuelwood characteristics and its relation with extractives and chemical properties of ten fast-growth species in Costa Rica. Biomass Bioenergy 2013, 56, 14-21. [CrossRef]

22. Vassilev, S.V.; Baxter, D.; Vassileva, C.G. An overview of the behaviour of biomass during combustion: Part II. Ash fusion and ash formation mechanisms of biomass types. Fuel 2014, 117, 152-183. [CrossRef]

23. Baernthaler, G.; Zischka, M.; Haraldsson, C.; Obernberger, I. Determination of major and minor ash-forming elements in solid biofuels. Biomass Bioenergy 2006, 30, 983-997. [CrossRef]

24. James, A.K.; Thring, R.W.; Helle, S.; Ghuman, H.S. Ash Management Review-Applications of Biomass Bottom Ash. Energies 2012, 5, 3856-3873. [CrossRef]

25. Pöykiö, R.; Mäkelä, M.; Watkins, G.; Nurmesniemi, H.; Dahl, O. Heavy metals leaching in bottom ash and fly ash fractions from industrial-scale BFB-boiler for environmental risks assessment. Trans. Nonferrous Met. Soc. China 2016, 26, 256-264. [CrossRef]

26. Kalembkiewicz, J.; Chmielarz, U. Ashes from co-combustion of coal and biomass: New industrial wastes. Resour. Conserv. Recycl. 2012, 69, 109-121. [CrossRef]

27. Rivero-Huguet, M.; Huertas, R.; Francini, L.; Vila, L.; Darré, E. Concentrations of As, Ca, Cd, Co, Cr, Cu, Fe, $\mathrm{Hg}, \mathrm{K} ., \mathrm{Mg}, \mathrm{Mn}, \mathrm{Mo}, \mathrm{Na}, \mathrm{Ni}, \mathrm{Pb}$, and $\mathrm{Zn}$ in Uruguayan rice determined by atomic absorption spectrometry. At. Spectrosc. 2006, 27, 48-55. [CrossRef]

28. Bonanno, G.; Cirelli, G.L.; Toscano, A.; Lo Giudice, R.; Pavone, P. Heavy metal content in ash of energy crops growing in sewage-contaminated natural wetlands: Potential applications in agriculture and forestry? Sci. Total Environ. 2013, 452-453, 349-354. [CrossRef] [PubMed]

29. Nieminen, M.; Piirainen, S.; Moilanen, M. Release of mineral nutrients and heavy metals from wood and peat ash fertilizers: Field studies in Finnish forest soils. Scand. J. For. Res. 2005, 20, 146-153. [CrossRef] 
30. Michelsen, O.; Solli, C.; Strømman, A.H. Environmental impact and added value in forestry operations in Norway. J. Ind. Ecol. 2008, 12, 69-81. [CrossRef]

31. Verma, M.; Loha, C.; Sinha, A.N.; Chatterjee, P.K. Drying of biomass for utilising in co-firing with coal and its impact on environment-A review. Renew. Sustain. Energy Rev. 2017, 71, 732-741. [CrossRef]

32. TruSpec Micro. Available online: https://www.leco.com/products/analytical-sciences/carbon-hydrogennitrogen-protein-sulfur-oxygen-analyzers/truspec-micro (accessed on 23 July 2018).

33. ISO/TC 44/SC 8. ISO 15296:2004, Gas Welding Equipment_Vocabulary_Terms Used for Gas Welding Equipment; Multiple; American National Standards Institute: Washington, DC, USA, 2007.

34. TC 107/WG 1, I. ISO 14918:1998, Thermal Spraying-Approval Testing of Thermal Sprayers; Multiple; American National Standards Institute: Washington, DC, USA, 2007.

35. Bhatt, B.P.; Tomar, J.M.S. Firewood properties of some Indian mountain tree and shrub species. Biomass Bioenergy 2002, 23, 257-260. [CrossRef]

36. Nirmal Kumar, J.I.; Patel, K.; Kumar, R.N.; Bhoi, R.K. An evaluation of fuelwood properties of some Aravally mountain tree and shrub species of Western India. Biomass Bioenergy 2011, 35, 411-414. [CrossRef]

37. Bhatt, B.P.; Tomar, J.M.S.; Bujarbaruah, K.M. Characteristics of some firewood trees and shrubs of the North Eastern Himalayan region, India. Renew. Energy 2004, 29, 1401-1405. [CrossRef]

38. Parikka, M. Global biomass fuel resources. Biomass Bioenergy 2004, 27, 613-620. [CrossRef]

39. Vázquez, G.; Antorrena, G.; González, J.; Freire, S. Studies on the composition of Pinus pinaster foliage. Bioresour. Technol. 1995, 51, 83-87. [CrossRef]

40. Keane, R.E. Wildland Fuel Fundamentals and Applications; Springer International Publishing: New York, NY, USA, 2015; ISBN 978-3-319-09014-6.

41. Reva, V.; Fonseca, L.; Lousada, J.L.; Abrantes, I.; Viegas, D.X. Impact of the pinewood nematode, Bursaphelenchus xylophilus, on gross calorific value and chemical composition of Pinus pinaster woody biomass. Eur. J. For. Res. 2012, 131, 1025-1033. [CrossRef]

42. Núñez-Regueira, L.; Rodríguez-Añón, J.; Proupín, J.; Romero-García, A. Energy evaluation of forest residues originated from pine in Galicia. Bioresour. Technol. 2003, 88, 121-130. [CrossRef]

43. Núñez-Regueira, L.; Rodríguez, J.; Proupín, J.; Mouriño, B. Forest waste as an alternative energy source. Thermochim. Acta 1999, 328, 105-110. [CrossRef]

44. Telmo, C.; Lousada, J.; Moreira, N. Proximate analysis, backwards stepwise regression between gross calorific value, ultimate and chemical analysis of wood. Bioresour. Technol. 2010, 101, 3808-3815. [CrossRef] [PubMed]

45. Álvarez-Álvarez, P.; Pizarro, C.; Barrio-Anta, M.; Cámara-Obregón, A.; Bueno, J.L.M.; Álvarez, A.; Gutiérrez, I.; Burslem, D.F.R.P. Evaluation of Tree Species for Biomass Energy Production in Northwest Spain. Forests 2018, 9, 160. [CrossRef]

46. Ye, T.H.; Azevedo, J.; Costa, M.; Semião, V. Co-Combustion of Pulverized Coal, Pine Shells, and Textile Wastes in a Propane-Fired Furnace: Measurements and Predictions. Combust. Sci. Technol. 2004, 176, 2071-2104. [CrossRef]

47. Biomass Energy Foundation: Woodgas Home Page. Available online: http://drtlud.com/BEF/proximat.htm (accessed on 26 July 2018).

48. Du, S.; Yang, H.; Qian, K.; Wang, X.; Chen, H. Fusion and transformation properties of the inorganic components in biomass ash. Fuel 2014, 117, 1281-1287. [CrossRef]

49. Countryman, C.M.; Philpot, C.W. Physical Characteristics of Chamise as a Wildland Fuel; Res. Paper PSW-RP-66; Pacific Southwest Forest \& Range Experiment Station, Forest: Berkeley, CA, USA, 1970; 16p.

50. Núez-Regueira, L.; Proupín-Castieiras, J.; Rodríguez-Aón, J.A. Energy evaluation of forest residues originated from Eucalyptus globulus Labill in Galicia. Bioresour. Technol. 2002, 82, 5-13. [CrossRef]

51. Bert, D.; Danjon, F. Carbon concentration variations in the roots, stem and crown of mature Pinus pinaster (Ait.). For. Ecol. Manag. 2006, 222, 279-295. [CrossRef]

52. Vassilev, S.V.; Baxter, D.; Andersen, L.K.; Vassileva, C.G. An overview of the chemical composition of biomass. Fuel 2010, 89, 913-933. [CrossRef]

53. Obernberger, I.; Biedermann, F.; Widmann, W.; Riedl, R. Concentrations of inorganic elements in biomass fuels and recovery in the different ash fractions. Biomass Bioenergy 1997, 12, 211-224. [CrossRef]

54. McGroddy, M.E.; Daufresne, T.; Hedin, L.O. Scaling of C:N:P stoichiometry in forests worldwide: Implications of terrestrial redfield-type ratios. Ecology 2004, 85, 2390-2401. [CrossRef] 
55. Antolín, G.; Irusta, R.; Velasco, E.; Carrasco, J.; González, E.; Ortíz, L. Biomass as an energy resource in Castilla y León (Spain). Energy 1996, 21, 165-172. [CrossRef]

56. Meetei, S.B.; Singh, E.J.; Das, A.K. Fuel wood properties of some oak tree species of Manipur, India. J. Environ. Biol. 2015, 36, 1007-1010. [PubMed]

57. Saravanan, V.; Parthiban, K.T.; Kumar, P.; Anbu, P.V.; Pandian, P.G. Evaluation of Fuel Wood Properties of Melia dubia at Different Age Gradation. Res. J. Agric. For. Sci. 2013, 1, 8-11.

58. Obernberger, I.; Thek, G. Physical characterisation and chemical composition of densified biomass fuels with regard to their combustion behaviour. Biomass Bioenergy 2004, 27, 653-669. [CrossRef]

59. Van Loo, S.; Koppejan, J. The Handbook of Biomass Combustion and Co-Firing; Earthscan: London, UK, 2008; Volume 1.

60. Felix, M. Future prospect and sustainability of wood fuel resources in Tanzania. Renew. Sustain. Energy Rev. 2015, 51, 856-862. [CrossRef]

61. McKendry, P. Energy production from biomass (part 1): Overview of biomass. Bioresour. Technol. 2002, 83, 37-46. [CrossRef]

62. Spinelli, R.; Magagnotti, N. Logging residue bundling at the roadside in mountain operations. Scand. J. For. Res. 2009, 24, 173-181. [CrossRef]

63. Guideline for Classification Classification of Ash from Solid Biofuels and Peat Utilised for Recycling and Fertilizing in Forestry and Agriculture (NT TR 613)—Nordtest.info. Available online: http:/ /www. nordtest.info/index.php/technical-reports/item/guideline-for-classification-classification-of-ash-fromsolid-biofuels-and-peat-utilised-for-recycling-and-fertilizing-in-forestry-and-agriculture-nt-tr-613.html (accessed on 26 July 2018).

64. Decreto-Lei 118/2006, 2006-2006-21. Available online: https:/ / dre.pt (accessed on 26 July 2018).

65. Misra, M.K.; Ragland, K.W.; Baker, A.J. Wood ash composition as a function of furnace temperature. Biomass Bioenergy 1993, 4, 103-116. [CrossRef]

66. Steenari, B.M.; Lindqvist, O. Stabilisation of biofuel ashes for recycling to forest soil. Biomass Bioenergy 1997, 13, 39-50. [CrossRef]

67. Pitman, R.M. Wood ash use in forestry-A review of the environmental impacts. Forestry 2006, 79, 563-588. [CrossRef]

68. Augusto, L.; Bakker, M.R.; Meredieu, C. Wood ash applications to temperate forest ecosystems-Potential benefits and drawbacks. In Plant and Soil; Springer: New York, NY, USA, 2008; Volume 306, pp. 181-198.

69. Sánchez-Rodríguez, F.; Rodríguez-Soalleiro, R.; Espaol, E.; López, C.A.; Merino, A. Influence of edaphic factors and tree nutritive status on the productivity of Pinus radiata D. Don plantations in Northwestern Spain. For. Ecol. Manag. 2002, 171, 181-189. [CrossRef]

70. Haraldsen, T.K.; Pedersen, P.A.; Grønlund, A. Mixtures of Bottom Wood Ash and Meat and Bone Meals as NPK Fertilizer. In Recycling of Biomass Ashes; Springer: New York, NY, USA, 2011; pp. 33-44.

71. Núñez-Regueira, L.; Rodríguez Añón, J.A.; Proupín Castiñeiras, J. Calorific values and flammability of forest species in Galicia. Coastal and hillside zones. Bioresour. Technol. 1996, 57, 283-289. [CrossRef]

(c) 2018 by the authors. Licensee MDPI, Basel, Switzerland. This article is an open access article distributed under the terms and conditions of the Creative Commons Attribution (CC BY) license (http:/ / creativecommons.org/licenses/by/4.0/). 